\title{
Arginase and kallikrein activities as biochemical indices of occupational exposure to lead
}

\author{
JADWIGA CHMIELNICKA, ELŻBIETA KOMSTA-SZUMSKA, AND \\ JADWIGA A SZYMAŃSKA
}

From the Department of Toxicological Chemistry, Institute of Environmental Research and Bioanalysis, Medical Academy of Lódź, 90-145 Lódż, Poland

ABSTRACT In a group of 60 workers occupationally exposed to lead the blood and urine lead concentrations, haematocrit, ALA-D and arginase activities, and urinary 5-aminolaevulinic acid (ALA) and coproporphyrin concentrations, and kallikrein activity were determined. Correlation coefficients of -0.78 and 0.77 for $\mathrm{Pb}-\mathrm{B} / \mathrm{ALA}-\mathrm{D}$ and $\mathrm{Pb}-\mathrm{B} /$ arginase were found respectively for lead concentrations above $40 \mu \mathrm{g} / \mathrm{dl}$ blood, and $0.82,0.76,0.74$, and -0.64 for $\mathrm{Pb}-\mathrm{U} / \mathrm{ALA}, \mathrm{Pb}-\mathrm{U} /$ $\mathrm{Cp}-\mathrm{U}, \mathrm{Pb}-\mathrm{U} / \mathrm{kallikrein}$, and $\mathrm{Pb}-\mathrm{U} /$ kallikrein, respectively. It seems that the increase in serum arginase activity may be indicative of liver damage while the decrease in kallikrein activity may indicate kidney damage in workers exposed to lead.

Tissues affected by lead absorption include the haemopoietic system, the central and peripheral nervous systems, kidneys, gastrointestinal tract, skeletal muscles, liver, immune system, reproductive system, and cardiac muscle. ${ }^{1}$ Biochemical tests for lead absorption and toxicity have been reviewed by several authors ${ }^{2-4}$ while others have discussed the action of lead on the liver ${ }^{1}$ and the kidney. ${ }^{5-7}$ Biochemical indicators of damage to tissues other than those concerned with haemopoiesis have not been greatly studied. ${ }^{1}$ 8-10

Early stages of damage to the internal organs may be signalled by changes in the activity of some enzymes in the urine or serum of workers exposed to lead. Particular attention has been given to urinary kallikrein. This enzyme (EC 3.4.21.8) releases bradykinin, a potent vasodilator polypeptide from an $a_{2}$-globulin called kininogen; urinary kallikrein excretion has been found to be very low in lead workers. ${ }^{11}$

Andreasik et al ${ }^{12}$ studied liver functions in lead workers and found a considerable increase in arginase (EC 3.5.3.1) activity to be the most characteristic symptom, other liver functions showing only small alterations. They concluded that these changes were indicative of damage to hepatocyte mitochondrial functions by lead.

The present study was designed to evaluate the suitability of using the measurement of arginase and

Received 11 July 1980

Accepted 15 August 1980 kallikrein activities to estimate exposure to lead by comparison with such classic tests ${ }^{1314}$ as the lead concentration in urine and blood, ALAD activity, or the levels of 5-aminolaevulinic acid (ALA) and coproporphyrins in urine.

\section{Material and methods}

Sixty lead workers were studied, from each of whom samples of blood and urine were collected. The activity of 5-aminolaevulinate dehydratase,,$^{15}$ and the haematocrit ${ }^{16}$ were estimated in whole blood and the activity of arginase was determined in serum using the method of Jergovic et al. ${ }^{17}$ In the urine samples ALA $^{18}$ and coproporphyrin ${ }^{19}$ concentrations were estimated together with the activity of kallikrein using Bergmeyer's method ${ }^{20}$ in which benzyl-Larginine ethyl ester (BAEE) is used as a substrate.

Blood and urine lead concentrations were determined by the dithizone method described elsewhere. ${ }^{21} 22$

Urinary lead, ALA, and coproporphyrin concentrations and kallikrein activity were estimated in 10 people having no occupational contact with lead compounds (control group).

\section{Results}

The ALAD and arginase activities and the blood lead concentrations are shown in the table. The data in this table are separated into two groups on the basis of the blood lead concentration. A twofold 
Results of determinations of biochemical indices and lead in blood (mean values and ranges)

\begin{tabular}{lllll}
\hline$P b-B \mu g / 100 d l$ & $N^{*}$ & $A L A D$ activity & ALAD activity ratio & Arginase activity \\
\hline$<40$ & & $0 \cdot 69$ & $0 \cdot 58$ & $2 \cdot 45_{\ddagger}^{+}$ \\
Mean: 27 & 31 & $(0 \cdot 27-1 \cdot 26)$ & $(0 \cdot 23-1 \cdot 10)$ & $(0-5 \cdot 7)$ \\
$>40$ & 26 & $0 \cdot 39$ & $0 \cdot 46$ & $4 \cdot 25+$ \\
Mean: 58 & $26 \cdot 10-0 \cdot 67)$ & $(0 \cdot 14-0 \cdot 88)$ & $(1 \cdot 2-10 \cdot 7)$ \\
\hline
\end{tabular}

* = Number of samples.

$\dagger=$ Activity ratio $=\frac{\Delta \mathrm{A} \text { at } \mathrm{pH} 6.8^{20}}{\Delta \mathrm{A} \text { at } \mathrm{pH} 6.0}$

$\ddagger=$ Statistically significant differences at $p=0.01$.

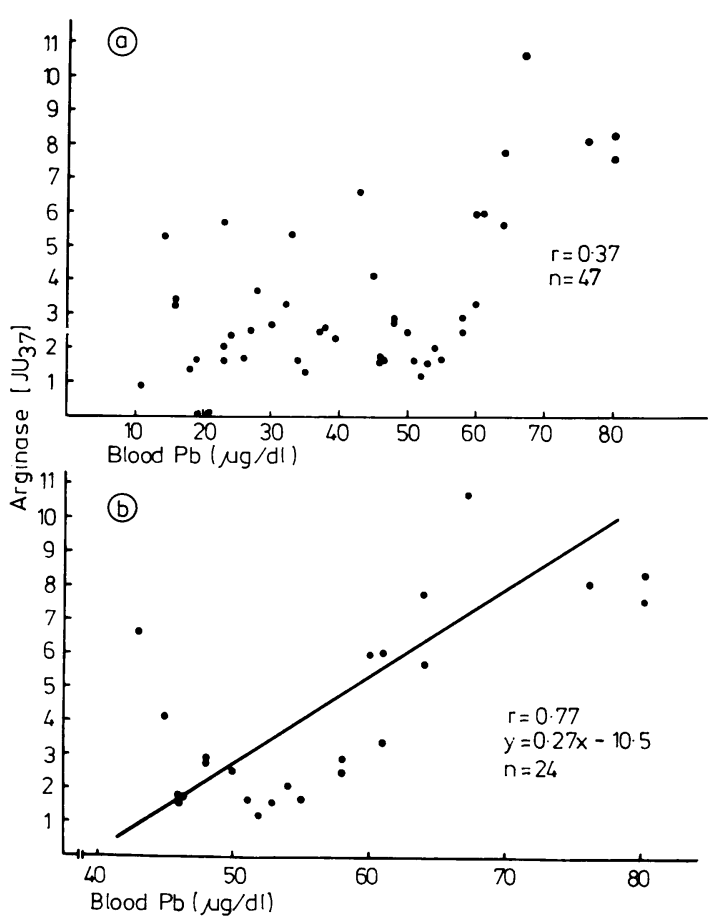

Fig 1 Correlation between activity of arginase and lead level in blood: (a) up to $40 \mu \mathrm{g} \mathrm{Pb/100} \mathrm{dl,} \mathrm{(b)} \mathrm{above} 40 \mu \mathrm{g}$ $\mathrm{Pb} / 100 \mathrm{dl}$.

increase in the blood lead concentration was accompanied by an almost twofold decrease in the ALAD activity while the arginase activity increased considerably. Figure 1 illustrates the dependence of arginase activity on the blood lead concentration. The correlation coefficient was low $(r=0.37)$ for the whole range of lead concentrations (fig 1(a)) but at higher lead concentrations (above $40 \mu \mathrm{g} / \mathrm{dl}$ ) a correlation coefficient of $r=0.77$ was found (fig 1(b)). The ALAD activity is plotted against the lead concentration in fig 2; a correlation coefficient of $r=0.78$ was obtained for the whole range of lead concentrations $(10-80 \mu \mathrm{g} / \mathrm{dl}$ blood).

In the urine from the control group the mean lead

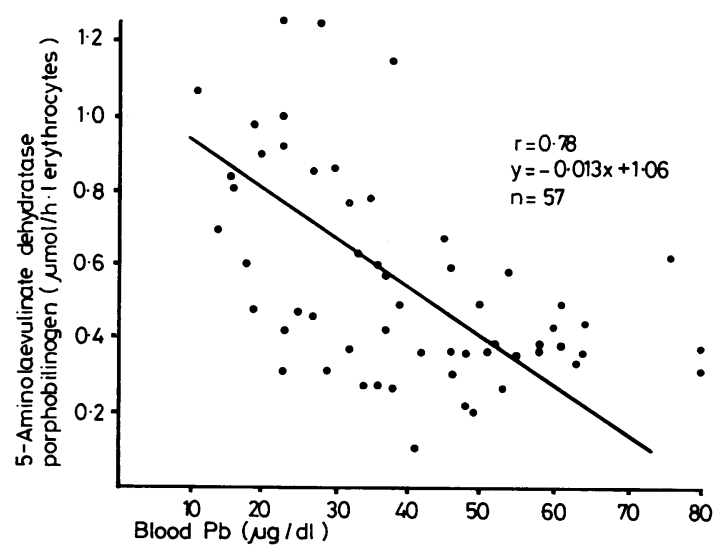

Fig 2 Correlation between activity of 5-aminolaevulinate dehydratase and lead concentration in blood.

concentration was $52 \mu \mathrm{g} / \mathrm{l}$, the mean ALA $4.5 \mathrm{mg} / \mathrm{l}$, and the mean coproporphyrin $9 \cdot 1 \mu \mathrm{g} / \mathrm{dl}$. In the urine of the lead workers, the mean lead concentration was $110 \mu \mathrm{g} / \mathrm{l}$, the mean ALA $8.0 \mathrm{mg} / \mathrm{l}$, and the mean coproporphyrin $15 \mu \mathrm{g} / \mathrm{dl}$.

From the results obtained, correlation coefficients were calculated between the various indices of lead exposure. The dependence of the delta-aminolaevulinic acid level on the lead concentration in urine is shown in fig 3(a) $(r=0.82)$. High correlation coefficients were also found between the urinary coproporphyrin concentration and delta-aminolaevulinate ( $\mathrm{r}=0.89$; fig $3(\mathrm{~b}))$ and between the CP-U and lead content of urine ( $r=0.76$; fig $3(\mathrm{c})$ ).

The kallikrein activity was estimated in the control group and in the group of workers of highest occupational lead hazard, the values obtained being $24 \cdot 8 \pm 2 \cdot 3 \mathrm{U} / 1$ and $16 \cdot 7 \pm 4 \cdot 5 \mathrm{U} / \mathrm{l}$, respectively. The correlation coefficient between kallikrein activity and the lead concentration in urine was -0.74 (fig 4(a)); that between the activity of this enzyme and the concentration of delta-aminolaevulinic acid was -0.64 (fig 4(b)). 

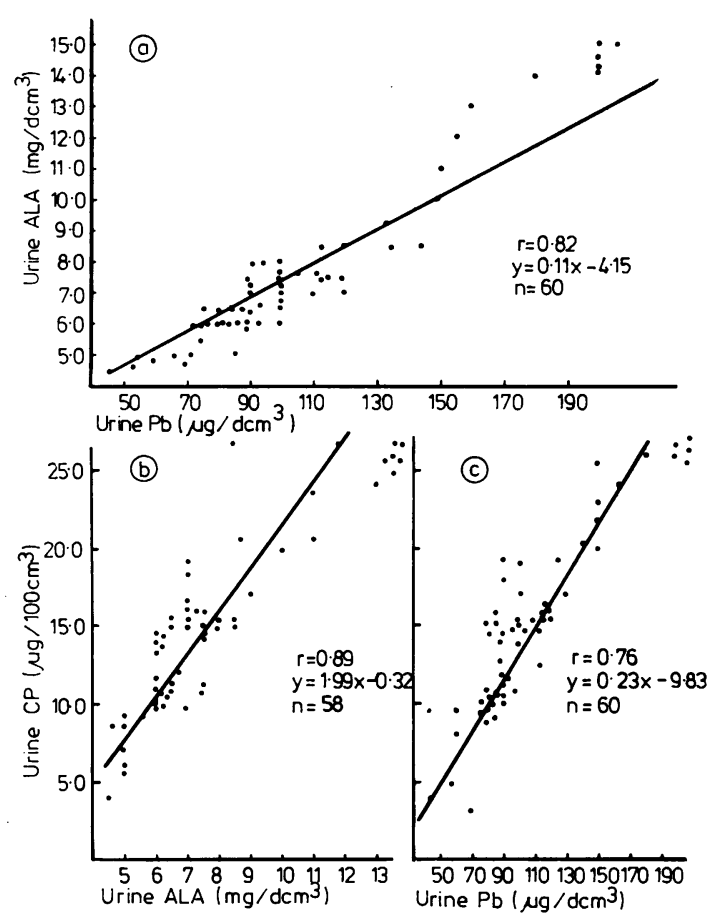

Fig 3 Correlations between concentrations: (a) deltaaminolaevulinic acid and lead in urine, (b) coproporphyrins and delta-aminolaevulinic acid, (c) coproporphyrins and lead in urine.
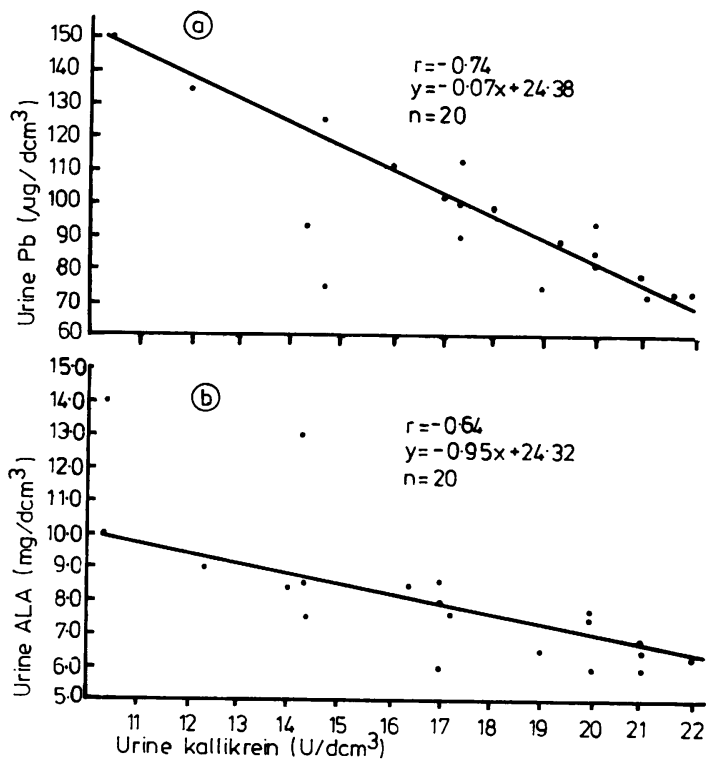

Fig 4 Correlations between activity of urinary kallikrein and: (a) lead concentration in urine, $(b)$ concentration of delta-aminolaevulinic acid in urine.

\section{Discussion}

The hazard from lead exposure has usually been estimated on the basis of blood lead concentrations, zinc-protoporphyrin concentration, the activity of 5 -aminolaevulinate dehydratase in the blood ${ }^{3}, 13$ and the estimation of the concentrations of lead, coproporphyrin, and ALA in the urine. ${ }^{23}$ None of these is linked to damage to the internal organs, however.

The results of this study indicate that enzymatic indices of liver (arginase) and kidney damage (kallikrein) may also be used in estimating occupational exposure to lead. These indices are found to correlate with the concentrations of lead in the blood and urine.

The concentration of arginase is $100-1000$-fold higher in the liver than in other organs; serum contains only trace amounts of this enzyme. ${ }^{24}$ This specific distribution of arginase can be maintained only if the integrity of the hepatocyte membranes is secured by energy-generating metabolic processes. Lead as a cytotoxic agent may disturb the cell energy metabolism resulting in the disintegration of cellular membranes and the liberation of arginase, an enzyme of relatively low molecular weight, into the serum.

The serum arginase activity was in the range 0 to 11 units at the lead concentrations found. Andreasik et $a^{12}$ found an upper limit of 49 units in lead workers (although they did not report the corresponding lead concentrations) with a mean of 4 units in a control group. In this study the exposed workers were divided into two groups, with the lead concentration in blood below and above $40 \mu \mathrm{g} \mathrm{Pb} / \mathrm{dl}$. The correlation between arginase activity and blood concentration in the group with the high lead was significant $(r=0.77$; fig $1(b))$. The difference in arginase activity between these two groups was statistically significant $(p=0 \cdot 01)$. A good correlation was also found between the ALAD activity and the lead concentration in blood $(r=0.78 ; f i g ~ 2)$, confirming earlier findings. ${ }^{15} 21$

It should be emphasised that, although the correlation coefficients between arginase and lead and ALAD and lead are of the same order of magnitude, the test based on the measurement of arginase activity may be more suitable for clinical purposes since it is indicative of damage to the liver. The biological role of ALAD and the consequences of the decrease in its activity are not clear. One must take into account, however, that an increase in serum arginase activity is also observed in cases of viral hepatitis, cirrhosis, chronic alcoholism, and acute myocardial infarct. ${ }^{24}$

As a result of this study the estimation of urinary kallikrein is also proposed as a new biochemical test of lead toxicity. An inverse correlation was shown 
between the kallikrein activity and the lead concentration in urine above $80 \mu \mathrm{g} \mathrm{Pb} / \mathrm{l}$ (corresponding to about $40 \mu \mathrm{g} \mathrm{Pb} / \mathrm{dl}$ blood).

According to the recommendations of a WHO committee, the upper permissible concentration of lead in the urine of people exposed to lead is about $100 \mu \mathrm{g} / \mathrm{l}$. The decrease in urinary kallikrein activity found with urine lead concentrations of $80 \mu \mathrm{g} \mathrm{Pb} / \mathrm{l}$ suggests that this enzyme may be a sensitive index of exposure to lead.

The values of the correlation coefficients: $\mathrm{Pb}-\mathrm{U} /$ ALA-U, Pb-U/Cp-U, and ALA-U/Cp-U reported here are similar to those found by other authors. 232526 The correlation coefficients kallikrein$\mathrm{U} / \mathrm{Pb}-\mathrm{U}$ and kallikrein/ALA-U were similar to those found for ALA-U/Pb-U and $\mathrm{Cp}-\mathrm{U} / \mathrm{Pb}-\mathrm{U}$. Although the biological function of kallikrein is still not completely understood, the decrease in the activity of this enzyme in the urine is probably due to disturbances of the synthesis of this enzyme in the kidneys, induced by the metal.

It is documented in published reports that the symptoms of renal damage in people exposed to lead are not typical and may be overlooked in practice. It seems, however, that changes in kallikrein activity in the urine can be detected earlier than anaemia.

\section{References}

1 Posner HS. Indices of potential lead hazard. Environ Health Perspect 1977;19:261-84.

${ }^{2}$ Albahary C. Lead and hemopoisiesis. Am J Med 1972;52: 367-72.

${ }^{3}$ Zielhuis RL. Dose-response relationships for inorganic lead: I Biochemical and hematological responses. Int Arch Occup Environ Health 1975;35:1-15.

4 Zielhuis RL. Dose-response relationship for inorganic lead: II Subjective and functional responses chronic sequelaeno response levels. Int Arch Occup Environ Health 1975; 35:19-26.

5 Vitale LV. Blood lead-an inadequate measure of occupational exposure. JOM 1975;17:155-226.

6 Wedeen RP. Occupational lead nephropathy. Am J Med $1975 ; 59: 630-5$.

${ }^{7}$ Hirsch GH. Effect of chronic lead treatment on renal function. Toxicol Appl Pharmacol 1973;25:84-92.

${ }^{8}$ Nordberg GE. Effect and dose-response relationships of toxic metals. Amsterdam: Elsevier, 1976.

9 O'Brien BJ, Smith S, Coleman DO. Lead pollution of the global environment. Progress Reports in Environmental
Monitoring and Assessment. 1980;1.

10 Piotrowski JK, O'Brien BJ. Analysis of the effects of lead in tissue upon human health using dose-response relationships. Progress Reports in Environmental Monitoring and Assessment. 1980;1.

${ }^{11}$ Boscolo P, Salimei E, Adamo A, Porcelli G. Effects of environmental lead levels on the urinary kallikrein excretion of exposed workers. Life Sci 1977;20:1715-22.

12 Andreasik Z, Gładysz A, Smolik R. Aktywnośc arginazy jako wskaźnik zaburzenia czynnošci wạtroby w przewlekle narażonych na związku ołowiu. II Krajowy Zjazd. Pol Tow Med Pracy Lódź 1978;42-3.

${ }^{13}$ Kisser W. Biochemische Methoden, zum Nachweis der Bleivergiftund. Arch Toxicol 1977;37:173-93.

${ }^{14}$ Lilis R, Velciukas J, Fischbein A, Andrews G, Selikoff IJ. Renal function impairment in secondary lead smelter workers: correlations with zinc protoporphyrin and blood lead levels. J Environ Pathol Toxicol 1979;2: 1447-74.

${ }^{15}$ Tomokuni K. Delta aminolevulinic acid dehydrataze test for lead exposure. Arch Environ Health 1974;29:274-81.

${ }^{16}$ Tomaszewski J. Mikrometody, biochemiczne w laboratorium klinicznym. Warsaw: Państwowy Zaktad Wydownictw Lekorskich, 1970.

${ }^{17}$ Jergovic J, Zuric J, Fiser-Herman M, Strauss B. A simple method for serum arginase determination. Clin Chim Acta 1970;30:765-74.

${ }^{18}$ Wada O, Toyokawa K, Urata G, Yano Y, Wakao K. A simple method for the quantitative analysis of urinary delta aminolaevulinic acid to evaluate lead absorption. Br J Ind Med 1969;26:240-3.

19 Heger-Aronsen B. Studies on urinary excretion of deltaaminolevulinic acid and other haem precursor in lead workers and lead-intoxicated rabbits. Scand J Clin Lab Invest 1960;12:suppl 47.

${ }^{20}$ Bergmeyer HU. Methods of enzymatic analysis. Verlag Chemie Academic Press Inc, 1974:1031-4.

${ }^{21}$ Chmielnicka J, Szymanska JA. Evaluation of methods for the estimation of 5-aminolulinate dehydratase for a broad range of lead concentrations in the blood of exposed workers. J Clin Chem Clin Biochem 1979;17: 373-7.

${ }^{22}$ Dutkiewicz T, Piotrowski JK, Kęsy-Dabrowska I. Chemiczne badania materiału biologicznego $\mathrm{w}$ toksykologii przemysłowej. Warsaw: Państwowy Zaktad Wydownictw Lekorskich, 1964.

${ }^{23}$ Benson GJ, George WHS, Litchfield MH, Seaborn DJ. Biochemical changes during the initial stages of industrial lead exposure. Br J Ind Med 1976;33:29-35.

${ }^{24}$ Szczeklik A. Enzymologia kliniczna. Warsaw: Państwowy Zaktad Wydownictw Lekorskich, 1975.

${ }^{25}$ Selander S, Cramer K. Interrelationships between lead in blood, lead in urine, and ALA in urine during lead work. Br J Ind Med 1970;27:28-39.

${ }^{26}$ Zielhuis RL. Interrelationships of biochemical response to the absorption of inorganic lead. Arch Environ Health 1971 ;23:299-311. 